\title{
Psychosocial Impact of COVID-19 on Elderly/Senior Population
}
A. Bevelaqua (Andrea Bevelaqua)1,6, C. Muss (Claus Muss)5,
Olah)1,2, R. Kovac (Robert Kovac) ${ }^{1,2}$, E. Horvatova (Eva Horvatova) $)^{3,4}$, Z. Ondrusova
(Zlata Ondrusova)2․ G. Magyarova (Gabriela Magyarova)2 ${ }^{2}$ E. Vrankova (Emilia
Vrankova)2, B. Igliarova (Bozena Igliarova)2, E. Haluskova (Eva Haluskova)2,
P. Gombita (Peter Gombita)1,2, M. Vladarova (Marketa Vladarova) ${ }^{2}$

${ }^{1}$ Integrative Group of Applied and Preventive Medicine, Vienna, Austria.

Original Article

${ }^{2}$ St. Pater Pio Institute Piestany, St. Cyrillus Methodius Institute Partizanske,

B1. Dr. P. Blaha Institute Skalica, St. Z.J. Malla Institute Kosice, B1. P.P. Gojdic, B1. D. Trska and B1. V. Hopko Presov, Michalovce, Spisska Nova Ves at St. Elizabeth University Institutes Nove Zamky St. Lesley College, SK.

${ }^{3}$ Dept. of Immunology Center Vienna, West Austria, Igap Vienna, AT.

${ }^{4}$ Slovak Medical University Bratislava, SK, School of Public Health/Medicine, SK.

${ }^{5}$ Vienna Gen Hospital, and SEUC Nursing Program Bratislava, Wahringer Grtl Vienna, AT.

${ }^{6}$ IGAP and Health Centre for Metabolism Zurich, $\mathrm{CH}$.

\section{E-mail address:}

igap@igap.ch

\section{Reprint address:}

Andrea Bevelaqua

IGAP Institute of Preventive Medicine

Ramistrasse 22

1007, Zurich

Switzerland

Source: Clinical Social Work and Health Intervention

Volume: 12

Issue: 4

Pages: $8-12$

Cited references: 19

\section{Reviewers:}

Selvaraj Subramaniam

Kuala Lumpur

Moses Kimon

Nairobi

\section{Keywords:}

Social Work at Elderly Population.

\section{Publisher:}

International Society of Applied Preventive Medicine i-gap

CSWHI 2021; 12(4): 8 - 12; DOI: 10.22359/cswhi_12_4_01 C Clinical Social Work and Health Intervention

\section{Abstract:}

Senior population is one of major social work and healthcare issues in highly developed countries. The aim of this study was assessing the late psychosocial consequences in seniors in 
Vienna and Bratislava after the first and second waves of the COVID-19 pandemics.

The results suggest that elderly patients in contrast to children and adolescents suffer significantly more late psychosocial consequences after having coronavirus acute or chronic disease.

\section{This paper is dedicated to Prof. Dr.h.c mult Peter G. Fedor Freyberg, ScD.}

\section{Introduction}

The combination of homelessness senior age/elderly with multiple comorbidities together with seasonal epidemic diseases such as influenza, COVID 19 etc. is a triple deadly synergy.(1-2) Elderly people who live alone or are homeless have poor nutritional and social status (1-12); access to preventive or therapeutic medications and vaccines for prevention; therapy not only against SARS and influenza but also for other comorbidities such as chronic obstructive $\mathrm{PD}$, hypertension. Another population at risk are small children and pregnant women among migrants (3-12). After being ill on COVID or other epidemic viral disease, post-COVID syndrome with psychosocial consequences frequently appear. The aim of this research is to assess if homeless seniors have more frequently psychosocial consequences than younger or middleaged homeless population.

\section{Methods}

In an open label comparative multi-centric prospective study performed in Košice and Bratislava, two cities connected by train and bus service in 2 hour intervals, we analyzed psychosocial consequences on 102 social work clients in 2 shelters or mobile intervention teams. (Oasis vs. Jarna \& Mea Culpa). A questionnaire in brief but guided dialogue plus Q\&A setting were used. 34 were seniors (age 63 and more) and 67 middle age or younger adults (29 to 62 years). Inclusion criterium was homelessness in the history at least for 3 months in last 2 years (incl). Inclusion criterium was a verbal history or undergoing COVID-19 in 2000/21 season (until June 30, 2021 from Apr 1, 2020).

\section{Results and discussion}

Psychosocial consequences such as: poor nutritional status; depression; fatigue disability for seasonal work; loss of appetite; weakness were compared. Depression, fatigue and weakness were more significantly $(\mathrm{P}<0.01$ and 0.001$)$ present in elderly versus non-elderly group.

Surprisingly, ability of seasonal work was not different among both groups, probably due to the low proportion of homeless individuals in the study, willing to accept seasonal work (13).

Access to medications both for COVID and non-COVID medicines (14-16) was low but non-significant among both groups. Another unexpected finding was willingness to receive vaccine both for influenza and COVID was high in both groups in contrast to previous study in children (17-19). The explanation of this phenomenon may result from similar findings from COVID studies in elderly patients and in migrants and homeless (19-24) where those groups accept vaccines more openly in contrast to primary healthy, younger and socially secure population (1-29).

\section{Conclusion}

In conclusion, the results were stimulating in terms of willingness to accept vaccination both for COVID or pandemic influenza, due to the poor social status and threat for vulnerable groups, with no difference between seniors and non-senior adults.

Late consequences, such as depression fatigue of weakness were significantly more observed among seniors, other possible consequences of past coronavirus infection such as poor nutritional status after infection or ability/willingness 
to work were similarly frequently represented in both groups.

Those findings can be used for the work of interventional social workers or vaccination/testing teams in pending homeless especially in elderly age, to easier combat the third pandemics wave and mitigate the upcoming seasonal influenza season.

\section{References}

1. EMARY KRW et al. (2021) Efficacy of ChAdOx1 nCoV-19 (AZD1222) vaccine against SARS-CoV-2 variant of concern 202012/01 (B.1.1.7): An exploratory analysis of a randomized controlled rial. Lancet 2021 Apr 10; 397:1351.

2. HAVERVALL $S$ et al. (2021) Symptoms and functional impairment assessed 8 months after mild COVID-19 among health care workers. JAMA 2021 Apr 7; [e-pub].

3. MIKOLASOVA G, MLYNARCIK P, BOZIK J, JACKULIKOVA M, PAVLOVICOVA A, OLAH M, KOVAC R, JANCOVIC M, DOKTOROV A, POLONOVA J, ZEMKO P, JURASEK M, ZABAVOVA S, BRYNDZAK P, TAZIAROVA M (2020) Cohortation and testing of elderly homeless within COVID pandemics in an Urban environment. In: Lekarsky obzor, vol. 69, nr. 11, 2020, ISSN 0457-4214, pp.381-382.

4. MASZLAK V, ZEMKO P, HERDICS G, JURASEK M, PAVLOVICOVA A, RADI F, BUNDZELOVA K, KOSTICOVA M, ZABAVOVA S, GOMBITA P, FABIAN A, MATEJOVA A, LACA P, VALACH M, SCHAVEL M, TONZA D (2020) Zero COVID-19 incidence among two large shelters of homeless population in rural settlement- in march-to july 2020: An important role of partial lockdown. In: Lekarsky obzor, (Med Horizon) vol. 69, nr. 11, 2020, ISSN 0457-4214, pp.379-380.

5. PALOCKOVA M, CHOVANCOVA S, SUGAROVA D, ZDILOVA E, SASVARY F, SASVARY M, BARKASI D, GULASOVA M, KMIT I, OLAH M, HOCHMAN R, HALUSKOVA E, PARTELOVA M, TRICHARD E (2020) COVID-19 has only temporarily interrupted social and health services in rural Albania in 2020. In: Clinical social work and health intervention, Vol.12, Nr. 1,
2021, ISSN 2076-9741/online ISSN 2222386X/Print, pp. 17-19.

6. NADDOUR A, TRILISINSKAYA I, KOZON V, HEIDLER P, CZARNECKI P, KONOSOVA H, JALILI N, DUBOVCOVA $\mathrm{M}$, BOSNAKOVA M, GIERTLIOVA D, GALLOVA A, PAUER K, UTESENA M, HUNADYOVA S, JACKULIKOVA M, HUNAKOVA L, SIMONEK T (2020) Scabies is the commonest skin/soft tissue infection (SSTI) in refugee children and adults escaping war from Middle East via Turkish and Ukrainian border. In: Lekarsky obzor, (Med Horizon), Vol. 69, Issue 5, 2020, ISSN 04574214, pp.170-172.

7. LULIAK M, GULAŠOVA M, VALLOVA J, BRADBURY R, GREY E, LIBOVA L, PROCHAZKOVA K, TOMANEK P, HOFBAUEROVA B, OTRUBOVA J, HUPKOVA I, SRAMKOVA M, TOPOLSKA A, JANCOVIC M, KATUNSKA M, KONOSOVA H, SUBRAMANIAM S (2019) Intervention of National Economies to Health and Social Security: Antibiotic Policy as an Example of EU Solidarity with Migration Crisis or Social Pathology? (Note) In: Clinical social work and health intervention, Vol.10, Nr. 4, 2019, ISSN 2076-9741/online ISSN 2222386X/Print, pp. 22-24.

8. SIMONEK T, JACKULIKOVA M, TOPOLSKA A, JANCOVIC M, JANOVICOVA L, SLUSNA L, HARDY M, VALACH M, SRAMKOVA M, POPOVICOVA M, BARKASI D, PROCHAZKOVA K, LIBOVA L, MRAZOVA M, VLCEK R, GULASOVA M, OTRUBOVA J, RADKOVA L, MURGOVA A, VANSAC P, HOCHMAN R, KONOSOVA H, KATUNSKA M, BAKOS M, BIELOVA M, SASVARY F, GREY E (2019) Spectrum of Communicable Diseases in Lesbos Island UNHCR Refugee Camp. In: Clinical social work and health intervention, Vol.10, Nr. 4, 2019, ISSN 2076-9741/online ISSN 2222-386X/Print, pp. 57-59.

9. TRILISINSKAYA I, SIMONEK T, JACKULIKOVA M, PROCHAZKOVA K, JANCOVIC M, BIELOVA M, BYDZOVSKY J, VLCEK R, KATUNSKA M, KONOSOVA H, GREY E, OTRUBOVA J, RADKOVA L, GULASOVA M, HRINDOVA T, LIBOVAL, MURGOVA A, SRAMKOVA A, HUPKOVA 
I, TOPOLSKA A, HOFBAUEROVA B, POPOVICOVA M, BAKOS M, HARDY M (2019) Changing Spectrum of Migrants entering Greek Refugee Camp 2019 in Comparison to 2015/2016. (Psychological and social challenge) (Letter to the editor), In: Clinical social work and health intervention, Vol.10, Nr. 4, 2019, ISSN 2076-9741/online ISSN 2222-386X/Print, pp. 60-62.

10. Sasvary F, Palockova M, Taziarova M, Hochmann R, Partelova J, Pavlovicova A, Bozik J, Valach M, Mlynarcik P, Kubik F, Haluskova E, Laca P, Roman L, Jurasek M, Olah M, Ondrusova Z, Bakos M, Hunadyova S, Luzny J, Toznar D, Bunova M, Zabavova S, Slavikova P, Radi F, Bryndzak P, Tkac V, Schavel M, Tomanek P, Roman L, Grey E (2020) Spectrum of communicable and noncommunicable diseases in an outpatient department unit during refugee and migrant second wave in 2020 in rural Albania. In: Lekarsky obzor, (Med Horizon) vol. 69, nr. 11, 2020, ISSN 0457-4214, pp. 396-397.

11. Pandya L, Phohla L, Bucko L, Palenikova M, Halcinova M, Mikloskova M, Konosova H, Libova L, Otrubova J, Murgova A, Cervenkova $\mathrm{M}$, Pauer $\mathrm{K}$, Hunyadyova $\mathrm{S}$, Bibza M (2020) Antimalnutrition program in low-cost children in rural regions in Karnataka state India and in Mandalay province, Myanmar In: Lekarsky obzor, (Med Horizon)Vol. 69, Issue 5, 2020, ISSN 0457-4214, pp. 162-164.

12. MIKOLASOVA G, NADDOUR A, SIMONEK T, BAKOS M, BUJDOVA N, KONOSOVA H, HEIDER P, CZARNECKI P, PAUER K, BIELOVA M, BYDZOVSKY J, JACKULIKOVA M, TRILISINSKAYA I, HUNADYOVA S, MRAZOVA M, HAJ ALI P, SUBRAMANINAN S, BENCA G (2020) Absence of outbreaks in UNHCR refugee camp in Greece. In: Lekarsky obzor, (Med Horizon) Vol. 69, Issue 5, 2020, ISSN 04574214, pp.168-169.

13. PROCHAZKOVA C, GREY E, MIKOLASOVA G, LIBOVA L, HUPKOVA I, PAUEROVA K, HOCHMAN R, JANCOVIC M, HOFBAUER B, SRAMKOVA $M$, STANKOVA P, MURGOVA A, KATUNSKA M, TOMANEK P, MIKLOSKOVA M, MIKLOSKO J, VLCEK R, PALENIKOVA
M, DRGOVA J, KOVAC R, KIMULI D, KALATOVA D, KOZON V, KONOSOVA H, POPOVICOVA M, HRINDOVA T, OTRUBOVA J (2019) Analysis of 9,896 Homeless Patients within an Urban Area in 2014 - 2019 - Social Pathology Leading to Poor Health, In: Clinical social work and health intervention, Vol.10, Nr. 4, 2019, ISSN 20769741/online ISSN 2222-386X/Print, pp. 6769.

14. KALATOVA D, SUBRAMANIAN S, LULIAK M, GULASOVA M, JANCOVIC M, PROCHAZKOVA K, HUPKOVA I, OTRUBOVA J, LIBOVA L, KATUNSKA M, POPOVICOVA M, TOPOLSKA A, SRAMKOVA M, HOFBAUEROVA B, MURGOVA A, KIMULI D (2019) Psychosocial and Medical Intervention before Emergency Travel in Humanitarian Workers - How early is not too late? In: Clinical social work and health intervention, Vol.10, Nr. 4, 2019, ISSN 20769741/online ISSN 2222-386X/Print, pp. 7072.

15. KAZUNGU KATANA J, HOLKOVA J, BENCA J, KMIT I, ONDRUSOVA Z, LACA P, GIERTLIOVA D, RUSNAK T, HORVATHOVA E, UTESENA M, HARDY M (2021) HIV mobile clinic as a part of the comprehensive social and public health program in the Malindi Coastal Area. In: Clinical social work and health intervention, Vol.12, Nr. 1, 2021, ISSN 2076-9741/online ISSN 2222-386X/Print, pp. 15-16.

16. RUSNAK T, ONDRUSOVA Z, OLAH M, BRYNDZAK P, LACA P, GIERTLIOVA D, KIMULI D, VASKO P, KMIT I, MULAMA K, GREY E (2021) St. Philippe rescue center in an area of high prevalence of HIV infection in Kisumu and street work for street boys in Nairobi. In: Clinical social work and health intervention, Vol.12, Nr. 1, 2021, ISSN 2076-9741/online ISSN 2222-386X/Print, pp. 20-22.

17. Mikloskova M, Hochman R, Jancovic M, Otrubova J, Sramkova M, Konosova H, Libova L, Murgova A, Pauer K, Utesena M, Seta S, Hoin L, Bujdova N, Dubovcova M, Bosnakova M, Giertliova D, Gallova A, Okoth V, Namulanda V, Kimuli D, Shahum A (2020) Low coverage of seasonal anti-influenza vaccination among orphanages in 
Cambodia, Kenya and Slovakia. In: Lekarsky obzor, Vol. 69, Issue 5, 2020, ISSN 04574214, pp.155-156.

18. LEVINE-TIEFENBRUN M et al. (2021) Initial report of decreased SARS-CoV-2 viral load after inoculation with the BNT162b2 vaccine. Nat Med 2021 Mar 29; [e-pub].

19. VASILEIOU E et al. (2021) Interim findings from first-dose mass COVID-19 vaccination roll-out and COVID-19 hospital admissions in Scotland: A national prospective cohort study. Lancet 2021 May 1; 397:1646; [epub]. 